IZA DP No. 9760

Social Contacts, Dutch Language Proficiency and Immigrant Economic Performance in the Netherlands: A Longitudinal Study

Barry R. Chiswick

Zhiling Wang

February 2016 


\title{
Social Contacts, Dutch Language Proficiency and Immigrant Economic Performance in the Netherlands: A Longitudinal Study
}

\author{
Barry R. Chiswick \\ George Washington University \\ and IZA \\ Zhiling Wang \\ Vrije Universiteit Amsterdam \\ and Tinbergen Institute
}

\section{Discussion Paper No. 9760 \\ February 2016}

\author{
IZA \\ P.O. Box 7240 \\ 53072 Bonn \\ Germany \\ Phone: +49-228-3894-0 \\ Fax: +49-228-3894-180 \\ E-mail: iza@iza.org
}

Any opinions expressed here are those of the author(s) and not those of IZA. Research published in this series may include views on policy, but the institute itself takes no institutional policy positions. The IZA research network is committed to the IZA Guiding Principles of Research Integrity.

The Institute for the Study of Labor (IZA) in Bonn is a local and virtual international research center and a place of communication between science, politics and business. IZA is an independent nonprofit organization supported by Deutsche Post Foundation. The center is associated with the University of Bonn and offers a stimulating research environment through its international network, workshops and conferences, data service, project support, research visits and doctoral program. IZA engages in (i) original and internationally competitive research in all fields of labor economics, (ii) development of policy concepts, and (iii) dissemination of research results and concepts to the interested public.

IZA Discussion Papers often represent preliminary work and are circulated to encourage discussion. Citation of such a paper should account for its provisional character. A revised version may be available directly from the author. 
IZA Discussion Paper No. 9760

February 2016

\section{ABSTRACT \\ Social Contacts, Dutch Language Proficiency and Immigrant Economic Performance in the Netherlands: A Longitudinal Study*}

Using longitudinal data on immigrants in the Netherlands for the years 1991, 1994, 1998, 2002, we examined the impacts of social contacts and Dutch language proficiency on adult foreign-born men's earnings, employment and occupational status. The main conclusions are as follows. On average, social contacts and a good mastery of the Dutch language enhance immigrants' economic performances. The effects are stronger for immigrants with low-skilltransferability than for immigrants with high-skill-transferability, and are stronger for economic migrants than for non-economic migrants. Contact with Dutch people and Dutch organisations unambiguously enhances all aspects of immigrants' economic performance, however, we found no evidence for the positive effect of co-ethnic contact on employment status.

JEL Classification: J15, J61, Z13

Keywords: social capital, Dutch language proficiency, labour market performance, Dutch immigrants, skill transferability

Corresponding author:

Zhiling Wang

Faculteit der Economische Wetenschappen en Bedrijfskunde

Vrije Universiteit Amsterdam

De Boelelaan 1105

1081 HV Amsterdam

The Netherlands

E-mail: z.wang.vu@gmail.com

* This paper has benefitted greatly from comments and suggestions made by Thomas de Graaff, Peter Nijkamp and participants at the $55^{\text {th }}$ ERSA conference, Lisbon. 


\section{Introduction}

Turks, Moroccans, Surinamese and Antilleans are the four largest immigrant ethnic minority groups in the Netherlands, and they earn around $20 \%$ less than the natives in the Dutch labour market, ceteris paribus (Van Ours and Veenman, 1999). The Turks and Moroccans were responsive to the 'guest workers' program by the Dutch government, and migrated to the Netherlands in large numbers in the 1960s. Family-reunification in the 1980s and second-generation children born in the Netherlands have then substantially increased the proportion of Turks and Moroccans in the Netherlands. The mass inflow of Surinamese took place after the decolonisation of Surinam in 1975, while large migrant groups from the Netherlands Antilles (still an autonomous area within the Kingdom of the Netherlands) have been arriving since the 1990s.

The economic integration of the four ethnic minorities requires a comprehensive understanding of immigrant economic success in Dutch society (Zorlu and Hartog, 2001). In this paper, we are particularly interested in how social contacts affect Dutch immigrant economic success. We propose the following research questions: to what extent does the ethnic composition of contacts affect immigrant economic success in the Netherlands? How do the effects vary across ethnicity, education level, age at migration, and occupation? A second focus is on the effect of acquiring local language. How does Dutch language proficiency contribute to the economic performance of these four groups?

Many empirical studies on social contacts and economic performance analysed crosssectional data, where the causal effect of social contacts is hard to infer (see, e.g., Kanas and Van Tubergen, 2006; Lancee, 2010; Lin et al., 1981). There is a paucity of studies of significant adjustment in a dynamic setting. Xue (2008) looks at the role of social networks using a longitudinal survey of immigrants to Canada, and finds that social capital facilitates employment, possibly through a more ethnically diverse network. Kanas et al. (2012) uses data from the German Socio-Economic Panel, and find that inter-ethnic ties with Germans lead to higher occupational status but not to increased income. Piracha et al. (2014) uses the Households Income and Labour Dynamics in Australia longitudinal data, and find a positive effect of social capital on migrants' employment outcomes and wages, especially for women. Moreover, it affects the employment probability of obtaining a white-collar job rather than a blue-collar one.

This paper contributes to the literature in several ways. First, we enrich the social network and labour market performance literature by distinguishing co-ethnic contact 
and inter-ethnic contact. Second, we add to the literature on the labour market effects of Dutch language proficiency in the Netherlands. Third, we study labour market outcomes more comprehensively than the previous literature by using three measures: labour market earnings, employment probability, and occupational status. Fourth, the Dutch immigrant data enables us to test the causal effect of social contacts and Dutch language proficiency more rigorously in a longitudinal setting.

The remainder of the paper is organised as follows. Section 2 proposes the theory and our hypotheses. Section 3 describes the data and variables. Section 4 presents the empirical analysis. Robustness checks are performed in Section 5, confirming our main results. The final section provides concluding remarks, and discusses avenues for future research.

\section{Theory and Hypotheses}

The literature both in labour economics and sociology is replete with references to the importance of social networks for labour market performance (mainly earnings and employment)(see, e.g., Granovetter, 1974; Ioannides and Loury, 2004; Montgomery, 1991). Social contacts facilitate economic opportunities by providing access to job information (Lin, 1999; Mouw, 2003). Equally important is the linguistic skill as a host-country specific human capital. The positive effect of destination language proficiency for immigrants' economic well-being has been widely acknowledged in English-speaking countries such as the US, Canada, Australia and the UK (Carliner, 1981; Chiswick and Miller, 1995; Chiswick and Miller, 2002; Dustmann and Fabbri, 2003; McManus et al., 1983), as well as non-English speaking countries such as Germany, Spain and Israel (Budria and Swedberg, 2012; Chiswick, 1998; Dustmann and Van Soest, 2001). Destination language proficiency directly enhances earnings and enhances the partial effect of other forms of human capital. Above all, it is then hypothesised that social contacts and Dutch language proficiency increase the likelihood of employment and earnings of non-western immigrants in the Netherlands. $\left(H_{1}\right)$

Immigrants' labour market performance is closely associated with skill transferability (Chiswick and Miller, 2012; Duleep and Regets, 1999), since low-skill-transferability immigrants will be making greater human-capital investment in the Netherlands. Skill transferability can be proxied empirically by age at migration, linguistic distance between origin and destination languages, and host-country specific education. High- 
skill-transferability immigrants are able to quickly adapt to the new environment by themselves, while social contacts and Dutch language proficiency could be more beneficial to low-skill-transferability immigrants due to their lack of host-country specific human capital. It is then hypothesised that social contacts and Dutch language proficiency have a greater impact on the likelihood of employment and earnings for low-skill-transferability immigrants than for high-skill-transferability immigrants in the Netherlands. $\left(\mathrm{H}_{2}\right)$

The effect of social contacts and Dutch language proficiency varies with migration motives. Economic migrants are those who move primarily because of their own economic opportunities, and are mostly described as ambitious and hard-working (Chiswick, 1999). Compared to non-economic migrants, such as tied movers, refugees and ideological migrants, they are likely to make greater use of social contacts and Dutch language skills to enhance their labour market performance. This leads to the hypothesis that social contacts and Dutch language proficiency have a greater impact on the likelihood of employment and earnings for economic migrants than for non-economic migrants. $\left(\mathrm{H}_{3}\right)$

Last but not the least, occupational attainment is an important but frequently neglected indicator of labour market performance in immigrant literature. Apart from years of schooling, training, qualifications, language skills (Chiswick and Miller, 2007; Evans, 1987; Nickell, 1982), social network have also been found to increase occupational status (Kanas et al., 2012; Lin et al., 1981; Mullan, 1989). Certain occupations require social skills and effective communication for success. Blue-collar jobs, such as agricultural workers and machine operators, require technical skills more than the worker's social network. For white-collar jobs, however, such as clerks and service workers, the work performance is closely related to how well they communicate with people. Therefore we hypothesise that social contacts and Dutch language proficiency have a greater impact on occupational status for white-collar jobs than for blue-collar jobs. $\left(H_{4}\right)$

We also analyse the extent to which immigrants in the Netherlands benefit from different types of social contacts. Upon arrival at the destination country, an immigrant faces choices of developing social capital with different types of people, among which ethnicity might be the most important dimension. Contact with the natives yields unambiguously positive returns because it provides immigrants with information on higher quality job offers and assistance in assimilation (Iosifides et al., 2007; Kazemipur, 2006; Lancee, 2012). However, the economic returns of co-ethnic contacts are less clear-cut. Lancee (2010) found that co-ethnic networks do not affect economic outcomes. On the one hand, socializing with co-ethnics provides assistance in job information and initial settlement (Chiswick and 
Miller, 2005; Clark and Drinkwater, 1998). Yet, while embedding into co-ethnic networks enhances ethnic solidarity, it retards contact with the host society. This may hamper upward economic mobility. ${ }^{1}$ Therefore we hypothesise that immigrant's contact with Dutch people leads to better economic performance (earnings, employment and occupational status) $\left(H_{5}\right)$, and that co-ethnic contact has an ambiguous effect on immigrant's economic performance (earnings, employment and occupational status) $\left(H_{6}\right)$.

\section{Data and Variables}

\subsection{Data}

The data are from the Dutch survey 'Social Position and Use of Public Facilities by Immigrants' (SPVA), which is a large-scale, cross-sectional survey for the four largest non-western immigrant groups in the Netherlands: Turks, Moroccans, Surinamese, and Antilleans. The aim of the survey is to collect information for the analysis of the socioeconomic and socio-cultural position of the four largest immigrant ethnic minorities in the Netherlands. The data were collected using a stratified random sampling method to target municipalities with a high percentage of immigrants. The empirical analysis is restricted to adult foreign-born men, with the age ranging from 25 to 64 years. The individuals included are those who were reported as the household head. The sample frame consists of 10 to 13 cities (depending on survey year), where immigrants are relatively overrepresented. It was conducted in year 1991, 1994, 1998 and 2002, with 1981, 1762, 3228, and 1949 households, respectively.

We follow the approach in Martinovic et al. (2009) to create a sample of panel respondents. A number of immigrants participated more than once in the survey. There are in total 718 two-waves participants, 118 three-waves participants, and 18 four-waves participants. Those who participated more than twice (for example a 1991-1994-1998 participant), are registered both as belonging to the 1991-1994 and 1994-1998 panel groups. As a result, a pooled data set of 1450 cases is obtained, with responses on two occasions that are separated by a time distance of 3 to 4 years. $^{2}$

\footnotetext{
${ }^{1}$ This classification of the two types of social contacts is more frequently called bonding and bridging by sociologists, according to the definitions in Putnam (2000) and Woolcock and Narayan (2000).

${ }^{2} \mathrm{~A}$ household which has changed its head across waves is excluded from the analysis.
} 


\subsection{Dependent and independent variables}

In the Appendix, Table A1 shows a list of the dependent and independent (explanatory) variables, with their detailed definitions and coding.

Three different variables jointly measure immigrant labour market performances. Monthly earnings: respondents report their monthly labour market earnings from all jobs. Employment: dichotomous variable equals 1 if the respondent is working regularly and 0 if the respondent is without a job, that is unemployed or searching for a job. ${ }^{3}$ Occupational status: it is measured in terms of the International Socio-Economic Index (ISEI) (Ganzeboom et al., 1992). It refers to the primary occupation reported in the survey year.

There are several explanatory variables:

Only employed respondents were asked about their working hours, occupations, and sectors. Contract working hours: the respondents were asked how many hours they work per week according to the employment contract. Occupations: occupations are categorised into two types. Blue-collar workers perform manual labour (e.g. agricultural workers and machine operators), and white-collar workers perform professional, managerial, or administrative work (e.g. service workers, clerks and legislators). ${ }^{4}$ Sectors: three types are distinguished. Primary sector involves activities of raw materials extraction (e.g. agriculture, horticulture, and forestry), secondary sector involves manufacturing activities (e.g. food processing and construction), and the tertiary sector involves services (e.g. telecommunication and accountants).

Human capital variables for both the origin-country and host-country are included. Education is measured by five dichotomous variables: No education, primary education, lower secondary education, intermediate education, and higher education. ${ }^{5}$ Education in

\footnotetext{
${ }^{3}$ Respondents who are not in the labour force are not included in the sample.

${ }^{4}$ Here we make use of the International Standard Classification of Occupation, ISCO-88, 1-digit level. ISCO codes (1) legislators, senior officials and managers, (2) professionals, (3) technicians and associate professionals, (4) clerks, (5) service workers and shop and market sales workers, are defined as white collar. ISCO codes (6) skilled agricultural and fishery workers, (7) craft and related trades workers, (8) plant and machine operators and assemblers, (9) elementary occupations, are defined as blue collar.

${ }^{5}$ According to Oosterbeek (1992), secondary education in the Netherlands is composed of both vocational and general branches, with different years of schooling. Within each branch, students can enter lower secondary education directly after primary education and can only enter intermediate education upon graduation from the previous one. Higher education refers to higher vocational education and university. We distinguish education as primary education (LO), lower secondary education
} 
$O C$ : the highest degree obtained in the country of origin, among the five levels. Education in $N L$ : the highest degree obtained in the Netherlands. Work experience in $O C$ : work experience in the country of origin is measured in years. Work experience in $N L$ : work experience in the Netherlands is measured in years. Dutch language proficiency: it is a categorical variable with (1) do not speak Dutch or find it very difficult, (2) Not very well, sometimes find it difficult, (3) Very well, never find it difficult, where (1) is the reference category.

Social capital variables are included for both co-ethnic contact and contact with Dutch people. Contact composition during free time: the respondents were asked about their frequency of Dutch contact and co-ethnic contact during free time. Three categories are, (1) more contacts with co-ethnics, (2) equal contacts with Dutch and co-ethnics, (3) more contacts with the Dutch, where (1) is the reference category. Contact composition at work: the respondents were asked about their frequency of Dutch contact and co-ethnic contact at work. Three categories are, (1) more contacts with co-ethnics, (2) equal contacts with Dutch and co-ethnics, (3) more contacts with the Dutch, where (1) is the reference category. Organisation membership: the respondents were asked whether they belong to any organisation and whether the composition of the organisation is predominantly Dutch or co-ethnic. Two questions are combined and a variable with three categories is constructed, (1) no membership, (2) member of a predominantly ethnic organisation, (3) member of a predominantly Dutch organisation, where (1) is the reference category.

Other background characteristics are included as well. Ethnicity: respondents self-report their ethnicity, including Turks, Moroccans, Surinamese, and Antilleans. The Turks are treated as the reference group. Municipality: respondent's place of residence. Amsterdam, Rotterdam, Den Haag, Utrecht, Eindhoven, Enschede, Almere, Alphen aan den Rijn, Bergen op Zoom, Hoogezand-Sappemeer, Delft, Dordrecht, and Tiel are identified in the survey and are included in the analysis. Amsterdam is the reference category. Ethnic concentration: is measured by the proportion of the respondent's ethnic group in the population of the city of residence, for Turks, Moroccans, Surinamese, and Antilleans. ${ }^{6}$ Nationality: dichotomous variable equals 1 if the respondent reported having Dutch nationality (citizenship) and 0 otherwise. Married: dichotomous variable equals 1 if the respondent is married (spouse present) and 0 otherwise. Number of children: the respondents were asked how many children they have at home in the Netherlands and also outside home. We create a new variable by summing up the numbers. Years since

(LBO/MAVO), intermediate education (MBO/HAVO/VWO), and higher education (HBO/WO).

${ }^{6}$ The ethnic distribution of population within cities is from Statistics Netherlands. 
migration: Years of stay in the Netherlands. Migration motives: migration motives are categorised into four types. Work, study, family (mainly family reunification, marriage or being brought to the Netherlands by parents) and other reasons (political situation in the origin-country, health reasons, etc).

\subsection{Descriptive statistics}

Table 1 presents descriptive statistics for cross-sectional data. The sample is restricted to adult foreign-born men, whose ages range from 25 to 64 . The average monthly earnings of the total sample is 2627 Dutch guilders. $58 \%$ of the immigrants are employed. The ISEI scale ranges from 16 (agricultural workers; helpers and cleaners in offices, hotels and other establishments) to 88 (medical doctors). The mean occupational status in the cross-sectional sample is 41 (locomotive-engine drivers). An increase of one standard deviation above the mean in the average ISEI scale would be equivalent to working as production and operations managers in wholesale and retail trade, or in transport, storage and communications. A decrease of one standard deviation below the mean would be equivalent to working as building caretakers, gardeners, or garbage collectors. $53 \%$ of the immigrants have a Dutch nationality. ${ }^{7}$ The average duration in the Netherlands is 18 years. Up to $69 \%$ of the respondents do not have any education in the Netherlands and only $6 \%$ completed higher education (university) in the Netherlands. $5 \%$ of the respondents work in the primary sector, $28 \%$ work in the secondary sector, $29 \%$ work in the tertiary sector, and the rest $38 \%$ are either unemployed, or students. The ethnic concentration is measured in percentages, with an average level of about $5 \%$.

\section{[TABLE 1 ABOUT HERE]}

Table 2 shows that social contacts and Dutch language proficiency vary significantly across the four ethnic groups. In general, Surinamese and Antilleans have more networks developed among Dutch people compared to Turks and Moroccans, either during free time, at work or organisation types. This may be a consequence of Dutch language proficiency. $85 \%$ of Surinamese speak Dutch very well, $72 \%$ for Antilleans, $28 \%$ for Moroccans, while only $20 \%$ of Turks reach this level of proficiency.

\footnotetext{
${ }^{7}$ In the Netherlands, it is possible to hold two nationalities. Some of the immigrants still keep their nationalities in the country of origin. The percentages of Dutch nationality holders in the sample are $34 \%$ for Turks and Moroccans, $95 \%$ for Surinamese, and $100 \%$ for Antilleans.
} 
[TABLE 2 ABOUT HERE]

Figure 1 shows the average monthly earnings of adult foreign-born men across ethnic groups. All groups show a steady increase in earnings over the years. Moroccans are economically worse off than the other three groups. Antilleans reported the highest earnings in 1991 and 1994, but were later surpassed by Surinamese in 1998 and 2002.

[Figure 1 ABOUT HERE]

\section{Empirical Results}

\subsection{Cross section analyses}

The empirics begin with a cross-section regression analysis for adult foreign-born men in the Netherlands. Table 3 presents the regression estimates for earnings, employment and occupational status. Column (1) is the OLS earnings regression (Mincer, 1974) incorporated with YSM variables (Chiswick, 1978). The dependent variable is the natural logarithm of earnings. The sample includes employed men reporting positive or non-zero labour market earnings. Column (2) is a logistic regression model and the dependent variable is a dichotomous variable for being employed or not. The sample includes those who reported 'working regularly' or 'unemployed/search for jobs'. Column (3) is an OLS estimation for occupational status, with ISEI being the dependent variable. The sample includes employed respondents with reported occupations. All the standard errors are clustered on respondent ID, given the fact that some respondents appear more than once in the pooled cross-sectional data.

\section{[TABLE 3 ABOUT HERE]}

In column (1) of Table 3 on earnings, the coefficients for all social contact variables are statistically insignificant. Dutch language proficiency turns out to be an important factor in increasing earnings. Respondents who speak Dutch very well earn around $6 \%$ more than those who have no mastery of the Dutch language. This effect is smaller than the effect of language proficiency found elsewhere in other destination countries. In 
addition, higher earnings are associated with more schooling in the Netherlands. Other variables the same, there is no significant difference in earnings among the four immigrant groups.

In column (2) of Table 3 on employment, the effects of social contacts and Dutch language proficiency on the probability of employment are interpreted using the odds ratio. The odds ratio is expected to change by $\exp \left(b_{i} \delta\right)$ for a change of $\delta$ in variable $x_{i}$, ceteris paribus.

$$
\frac{\operatorname{Pr}\left(\text { Employed }=1 \mid X=\left\{x_{i}+\delta, x_{-i}\right\}\right)}{\operatorname{Pr}\left(\text { Employed }=1 \mid X=\left\{x_{i}, x_{-i}\right\}\right)}=\exp \left(b_{i} \delta\right),
$$

where $b_{i}$ is the estimated coefficient for variable $x_{i}$ in the logistic regression model. The odds ratio is 1.31 times greater for a change from 'more contact with co-ethnics' to 'equal contacts with Dutch and co-ethnics' in the ethnic composition. The odds ratio is 2.26 times greater for a change from 'speak no Dutch' to 'speak Dutch very well'. Surinamese and Antilleans have higher employment rates than Turks and Moroccans. ${ }^{8}$

In column (3) of Table 3, ethnic organisation membership and Dutch organisation membership are both associated with a higher occupational status. The occupational status is positively associated with education level. The negative coefficient for YSM (although not statistically significant) and the significant positive coefficient for YSM squared suggest that the International Socio-Economic Index rises at an increasing rate with duration in the Netherlands. ${ }^{9}$

\subsection{Panel data analyses on earnings}

This subsection discusses the econometric specifications for testing immigrant economic assimilation using longitudinal data, and the corresponding regression analysis. The following notation is used: $L n E_{i t}$ is the natural logarithm of earnings for immigrant $i=1,2, \cdots, N$, in time period $t ; Y S M_{i t}$ is years since migration of $i$ in time $t ; X_{i t}$ is the individual characteristics that may vary over time, for example, social contact variables and language variables; $\theta_{i}$ is the individual specific effect for immigrant $i$, including observed characteristics (such as ethnicity), and unobserved heterogeneity; $\varepsilon_{i t}$ is the

\footnotetext{
${ }^{8}$ This is consistent with the finding in Zorlu and Hartog (2008).

${ }^{9}$ Zorlu (2013) shows that labour market adjustment of immigrants in the Netherlands runs through inter-occupational job mobility, rather than intra-occupational mobility, while the focus is put more on the initial disadvantage upon arrival and the rate of adjustment (including interval categories for YSM as the explanatory variable, but not quadratic terms of YSM) in later years.
} 
residual error.

We follow convention by assuming that the earnings assimilation curve is quadratic in years since migration:

$$
L n E_{i t}=\alpha+\beta \cdot Y S M_{i}+\gamma \cdot Y S M_{i}^{2}+\lambda \cdot X_{i t}+\theta_{i}+\varepsilon_{i t} .
$$

The intercept $\alpha$ could be interpreted as the logarithm of the benchmark for immigrant group evaluated at $X_{i}=0$. It is assumed that our interested coefficients $\beta, \gamma$ and $\lambda$ do not vary over time. For simplicity, it is assumed that the effect on earnings of education in the Netherlands is captured by the years since migration variable.

Let $\tau=t+T$ where $T>0$ is the time interval between two longitudinal observations. Let $\Delta_{T}$ denote the difference operator over T periods. Equation 2 implies that in time period $\tau$ :

$$
L n E_{i \tau}=\alpha+\beta \cdot\left(Y S M_{i}+T\right)+\gamma \cdot\left(Y S M_{i}+T\right)^{2}+\lambda \cdot X_{i \tau}+\theta_{i}+\varepsilon_{i \tau} .
$$

Subtracting Equation 3 from Equation 2 differences away the immigrant specific effect:

$$
\Delta_{T} L n E_{i}=\left(\beta T+\gamma T^{2}\right)+2 T \gamma \cdot Y S M_{i}+\lambda \cdot \Delta_{T} X_{i}+\Delta_{T} \varepsilon_{i}
$$

$\beta, \gamma$, and $\lambda$ are exactly identified in Equation 4. Note the sign of $\gamma$ determines whether the immigrant earnings increase at an increasing or a decreasing rate with duration in the destination.

The panel data sample is created with a time interval of $T \approx 4$ years between the first and the second time of the survey, making it possible for us to estimate Equation 4. The variable $X_{i}$ include the social capital variables (Contact composition during free time, contact composition at work, and organisation membership) and Dutch language proficiency variable discussed in subsection 3.2. The longitudinal regression analysis would be concerned with the level changes in social contacts and Dutch language proficiency between two time periods.

Table 4 presents the longitudinal regression analysis of earnings for adult foreign-born men in the Netherlands. The dependent variable is the difference between the natural logarithm of earnings adjusted for inflation in time 2 and time 1. Column (1) 'All' is the estimation for the whole sample. In column (1), contrary to the cross-sectional findings, 
it is found that the coefficients for social contacts are statistically significant. Co-ethnic contact during free time compared to Dutch contact (16\%), equal contact compared to co-ethnic contact at work $(17 \%)$ and Dutch language proficiency compared to not speaking Dutch $(15 \%)$ all lead to an increase in earnings. ${ }^{10}$ The effect of network differs by the context. If an immigrant allocates more time in co-ethnic contact during free time or some contact at work with Dutch people compared to only co-ethnics, this would yields returns to earnings. These confirm our hypotheses $H_{1}, H_{5}, H_{6}$ about earnings.

\section{[TABLE 4 ABOUT HERE]}

Column (2) of Table 4 'T\&M' is the estimation for the Mediterranean group (Turks and Moroccans), and column (3) of Table 4 ' $\mathrm{S} \& \mathrm{~A}$ ' is the estimation for the Caribbean group (Surinamese and Antilleans). The Mediterranean group is predominantly of Muslim origin and its linguistic distance from the Dutch is great. The Caribbean group, however, is close to the Dutch society concerning religious and cultural characteristics due to a colonial history. Column (2) shows that co-ethnic contact compared to equal contact (14\%), some contact with Dutch people at work (17\%), and Dutch language proficiency (15\%) all lead to an increase in earnings for the Mediterranean group, while the effect is much lower for the Caribbean group. As shown in equation 4, solving $\beta T+\gamma T^{2}=0.204,2 T \gamma=-0.011$ yields $\beta=0.057$ and $\gamma=-0.0014$ (Table 4,column 2). The earnings of the Mediterranean group increases at a decreasing rate with duration.

Column (4) of Table 4 'No NL Edu.' is the estimation for immigrants who completed their education in the country of origin, and column (5) of Table 4 'NL Edu.' is the estimation for immigrants who completed education in the Netherlands. Comparing column (4) and column (5), the effects of social contacts (15\% for 'more contact with Dutch at work') and Dutch language proficiency (19\%) on earnings of immigrants who completed their education in the country of origin are stronger than that for immigrants

\footnotetext{
${ }^{10}$ Yao and Van Ours (2015) analyses the effect of Dutch language proficiency on the wages of adult male immigrants in the Netherlands from all countries of origin. Although the sample is relatively small for a microdata analysis of male earnings (407 observations), those who are proficient in Dutch (measured by a dichotomous variable) earn about 14 percent more than those lacking proficiency, which is marginally significant $(t=1.91)$. This magnitude is comparable to what is found in this study and in studies of other countries. Using an IV approach to identify Dutch proficiency, Yao and Van Ours found the coefficient declines to 9.4 percent, but the standard error increases sharply $(t=0.49)$. Presumably because of the difficulty of finding appropriate identifying instruments, other studies using the IV technique to study the relation between earnings and proficiency also found a large increase in the standard error compared to an OLS analysis. For a discussion of this issue, see Chiswick and Miller (1995).
} 
who completed their education in the Netherlands.

Column (6) of Table 4 'AAM $>18$ ' is the estimation for immigrants whose age at migration (AAM) is older than 18 , and column (7) of Table 4 ' $\mathrm{AAM} \leq 18$ ' is the estimation for immigrants whose age at migration (AAM) is younger than 18. Comparing column (6) and column (7), co-ethnic contact during free time (22\%), Dutch contact at work $(23 \%)$, and Dutch language proficiency (19\%) all increase earnings for immigrants who migrate at an older age, while only the coefficient for Dutch organisation membership is positively significant in column (4). The effects of social contacts and Dutch language proficiency on earnings of immigrants who migrate at an older age are also slightly stronger than that for immigrants who migrate at a younger age.

Above all, we have done regressions for three pairs of (low-skill-transferability versus high-skill-transferability) subgroups: the Mediterranean versus the Caribbean; immigrants' education completed in the country of origin versus education completed in the Netherlands; age at migration older than 18 versus age at migration younger than 18 . We consistently found that low-skill-transferability immigrants benefit more from social contacts and especially from Dutch language proficiency in earnings than high-skilltransferability immigrants, thus confirming hypothesis $H_{2}$ about earnings.

Column (8) of Table 4 'Econ' is the estimation for the economic migrants, and column (9) of Table 4 'Non-Econ' is the estimation for the non-economic migrants. Column (8) shows that the statistically significant contact with Dutch people at work $(31 \%)$ and Dutch language proficiency (24\%) both lead to an increase in earnings of economic migrants. However, among non-economic migrants, only the coefficient for Dutch organisation membership is statistically significant $(16 \%)$. This confirms our hypothesis $H_{3}$ on the effects on earnings of motives for migrating.

\subsection{Panel data analyses on employment}

Appendix Table A2 presents the random effects logistic regression results of employment for adult foreign-born men in the Netherlands. The random effects logit model is a maximum likelihood solution where the parameters are estimated through a weighted combination of within and between individual covariances. The dependent variable is a dichotomous variable for being employed or not. Column (1) 'All' is the estimation for the whole sample. $\sigma$ is the estimated random effects' standard deviation. The significance 
of $\sigma$ implies that there is random effect. Similar with cross-sectional findings in Table 3, Dutch contact greatly enhances the probability of being employed. In column (1), participating in a Dutch organisation is significantly associated with a higher probability of being employed, and the odds ratio is 4.93 times higher. The odds ratio is 1.76 times greater for a change from 'do not speak Dutch' to 'Dutch: not very well', and is 3.06 times greater for a change from 'do not speak Dutch' to 'Dutch: very well'. Social contacts and Dutch language proficiency turn out to increase the likelihood of employment, especially contact with Dutch people. Co-ethnic contact does not seem to have any positive effect on employment. These confirm the hypotheses $H_{1}, H_{5}, H_{6}$ about employment.

Column (2) of Table A2 'T\&M' is the estimation for the Mediterranean group (Turks and Moroccans), and column (3) of Table A2 'S\&A' is the estimation for the Caribbean group (Surinamese and Antilleans). Only the Mediterranean group has a higher probability of being employed with more Dutch contact, and a higher level of Dutch language proficiency. Social contacts and Dutch language proficiency do not have these positive effects for the Caribbean group, perhaps because they are highly adjusted to Dutch culture and language at immigration.

Column (4) of Table A2 'No NL Edu.' is the estimation for immigrants who completed their education in the country of origin, and column (5) of Table A2 'NL Edu.' is the estimation for immigrants who completed education in the Netherlands. In column (4), participating in a Dutch organisation is significantly associated with a higher probability of being employed for immigrants who completed their education in the country of origin, and the odds ratio is 9.97 times higher. The odds ratio is 1.74 times greater for a change from 'do not speak Dutch' to 'Dutch: not very well', and is 2.24 times greater for a change from 'do not speak Dutch' to 'Dutch: very well'. However in column (5), none of the coefficients for social contacts and Dutch language proficiency are significant for immigrants who completed their education in the Netherlands.

Column (6) of Table A2 'AAM $>18$ ' is the estimation for immigrants whose age at migration (AAM) is older than 18 , and column (7) of Table $\mathrm{A} 2$ 'AAM $\leq 18$ ' is the estimation for immigrants whose age at migration (AAM) is younger than 18. Comparing these two columns, the coefficients for Dutch organisation membership and Dutch language proficiency are positively significant for immigrants who migrated at older age, while only the coefficient for language variable is positively significant for immigrants who migrated at younger age. 
Above all, we have compared the three pairs (low-skill-transferability versus high-skilltransferability) of subgroups: the Mediterranean versus the Caribbean; education completed in the country of origin versus education completed in the Netherlands; age at migration older than 18 versus age at migration younger than 18 . We consistently found that low-skill-transferability immigrants benefit more in terms of employment from social contacts and Dutch language proficiency than high-skill-transferability immigrants, thus confirming hypothesis $H_{2}$ about employment.

Column (8) and (9) of Table A2 report the random effects regression results separately for economic and non-economic migrants. Participating in a Dutch organisation is significantly associated with higher probability of employment for economic migrants, and the odds ratio is 11.99 times higher. The odds ratio is 2.49 times greater for a change from 'do not speak Dutch' to 'Dutch: not very well'. However, the effect of language is much less for non-economic migrants. This confirms our hypothesis $H_{3}$ about employment.

\subsection{Panel data analyses on occupational status}

The fixed effects estimation on occupational status for adult foreign-born men in the Netherlands is reported in Table A3. The dependent variable is the International Socio-Economic Index (ISEI). The model eliminates unobserved heterogeneity by using deviations from the means of the variables, and hence the time-invariant variables, such as ethnicity, are eliminated. Column (1) is the estimation for the whole sample. Column (2) is the estimation for immigrants who are blue-collar workers, and column (3) is the estimation for immigrants who are white-collar workers. In column (1), it is found that both co-ethnic contact and contact with Dutch people are useful for occupational upward mobility. This confirms the hypotheses $H_{5}$ and $H_{6}$ about occupational status. Comparing column (2) and column (3), we do not find any significant effect of social contacts on occupational status in blue-collar jobs. In white collar-jobs, however, co-ethnic contact and some contact with Dutch people compared to only co-ethnics increases the occupational status. This confirms our hypothesis $H_{4}$. 


\section{Robustness Checks}

In this section, we mainly discuss two issues: selectivity of panel respondents in crosssectional data; and the possible reverse causality between earnings and social contact variables.

It should be noted that this Dutch survey was not originally set up as a longitudinal study and hence the level of attrition is rather high. Around $80 \%$ agree to take part in the next wave, but only $20 \%$ actually realise the re-interview. The interviewers did not trace the respondents who move in the period between the two surveys. We also checked the descriptive statistics for the pooled panel data, both at the first and the second time of measurement. They do not differ greatly from Table 1 and Table $2 .{ }^{11}$ To further check whether these respondents are selective, we apply Heckman selection model. In the first step, a probit regression is run to predict the participation of respondents in the panel sample. Apart from all the control variables, the dummy for living in a rented house is added. The coefficient is significantly negative, implying that the respondents who live in a rented house are less likely to participate in the next wave compared to those who own a house. The intuition is that respondents renting a house have higher probabilities of changing address by returning to their country of origin or moving elsewhere in the Netherlands. In the second step, the outcome regression is run controlling for the selectivity coefficient obtained in the first step.

The Heckman selectivity correction models for earnings, employment and occupational status are reported in Appendix Table A4. The inverse Mills' ratio reported in the last row of each column is not significant in any of the specifications, implying that there is no selection bias. This result validates the empirical analysis for the panel data.

Apart from utilising the longitudinal approach to tackle the endogeneity problem, we further study the causal relationship between social contacts and earnings by including in the model lagged measures of social contacts and Dutch language proficiency, (Appendix Table A5). In our panel data sample, these lagged variables are 3 to 4 years prior to the measured earnings.

Although the lagged contact variables during free time and at work are not statistically significant, lagged variables for ethnic organisation membership, Dutch organisation membership and the ethnic concentration all have significant positive effects in earnings.

\footnotetext{
${ }^{11}$ The descriptive tables for the pooled panel data are available on request.
} 
The ethnic organisation membership effect $(15 \%)$ is larger and more highly significant than the effect of Dutch organization membership (11\%). The lagged language variables are not statistically significant implying that recently acquired language skills have the bigger impact on earnings, as it is unlikely that higher earnings increases a worker's Dutch language skills.

\section{Main Conclusions and Discussions}

This paper studies the effects of social contacts and Dutch language proficiency on the adult foreign-born men's labour market performances in the Netherlands, using four large cross-section samples from year 1991 to 2002, together with a constructed panel dataset. It is found that social contacts and Dutch language proficiency have positive impacts on labour market outcomes (mainly employment and earnings). But the strength of the effects varies by the degree of the transferability of their pre-migration skills and their motivation for migration (economic or non-economic).

There are several important findings. First, the Mediterranean group (Turks and Moroccans) benefits much more from social contacts and Dutch language proficiency in their economic performance than the Caribbean group (Surinamese and Antilleans). For example, the Mediterranean immigrants who speak Dutch well earn $15 \%$ more than those who do not speak Dutch at all. For Turks and Moroccans, two economically disadvantaged groups with lower education levels, contact with Dutch people turns out to be of great use in job-related activity. Surinamese and Antilleans' earnings are quite invariant to changes in social contacts and Dutch language proficiency. Surinamese and Antilleans, as two immigrant groups that are closer to Dutch culture and language due to colonial ties, their pre-migration contacts with Dutch were rather frequent. The marginal effect of contact with Dutch people in the Netherlands is not that important for them.

Second, immigrants who completed their education in the country of origin benefit more from social contacts and Dutch language proficiency in their economic performances than immigrants who had some years of schooling in the Netherlands. In the former group, immigrants who report more contact with Dutch at work earn $15 \%$ more than those who have more co-ethnic contact at work, ceteris paribus. Certain qualifications in the Netherlands are useful to get a job or a promotion at work. Immigrants who completed their education in the country of origin lack the destination-specific exposure, and hence 
social contacts provide more information for them to familiarize with the local labour market.

Third, immigrants who migrated at an older age have a larger partial effect from social contacts and Dutch language proficiency in their economic performances than immigrants who migrated at a younger age. The older age an immigrant migrates, the less transferable is his skill to the destination. Younger migrants have accumulated more destinationspecific qualifications and mostly speak fluent Dutch. Therefore they are more competitive in job market than those who migrated at an older age.

Fourth, social contacts and Dutch language proficiency have larger impacts on the economic outcomes of economic migrants than non-economic migrants. Economic migrants make better use of social contacts and Dutch language proficiency to obtain economic benefits. For example, ceteris paribus, contact with Dutch at work and having a good mastery of Dutch yield $31 \%$ and $24 \%$ increases in earnings, respectively, while they do not have any significant effects on non-economic migrants' earnings.

Fifth, social contacts and Dutch language proficiency also enhance occupational status, but only for white-collar jobs. Contact with Dutch people is found to be consistently positive in increasing all labour market outcomes (earnings, employment and occupational status), but co-ethnic contact does not increase the likelihood of employment among immigrants.

This study demonstrates the importance of social contacts and the distinction between contacts among co-ethnics and with the host population, and Dutch language proficiency on immigrant economic outcomes. As a result, the study provides insights for the Netherlands, and the European Union more broadly, on programs to enhance the integration of immigrants by the government, immigrant ethnic communities and the immigrants themselves. ${ }^{12}$ A greater scope may involve mixed neighbourhood housing, which facilitates communications between the immigrants and the natives. A greater emphasis on Dutch language proficiency would enhance their earnings directly and enhance their earnings indirectly by facilitating contact with Dutch people during their free time, at work and through participating in Dutch organisations.

\footnotetext{
${ }^{12}$ Wang (2016), for example, studies how local labour market conditions affect immigrant's decision on network formation both in the co-ethnic group and the native group.
} 


\section{References}

Budria, S. and P. Swedberg (2012). 'The impact of language proficiency on immigrants' earnings'. IZA Discussion Paper 6957.

Carliner, G. (1981). 'Wage differences by language group and the market for language skills in Canada'. The Journal of Human Resources 16.3, pp. 384-399.

Chiswick, B. R. (1978). 'The effect of Americanization on the earnings of foreign-born men'. Journal of Political Economy 86.5, pp. 897-921.

Chiswick, B. R. (1998). 'Hebrew language usage: determinants and effects on earnings among immigrants in Israel.' Journal of Population Economics 11.2, pp. 253-271.

- (1999). 'Are immigrants favorably self-selected?' The American Economic Review 89.2, pp. $181-185$.

Chiswick, B. R. and P. W. Miller (1995). 'The endogeneity between language and earnings: international analyses'. Journal of Labor Economics 13.2, pp. 246-288.

Chiswick, B. R. and P. W. Miller (2002). 'Immigrant earnings : language skills, linguistic concentrations and the business cycle'. Journal of Population Economics 15.1, pp. 3157 .

Chiswick, B. R. and P. W. Miller (2005). 'Do enclaves matter in immigrant adjustment?' City $\&$ Community 4.March, pp. 5-35.

Chiswick, B. R. and P. W. Miller (2007). 'Earnings and occupational attainment: immigrants and the native born'. IZA Discussion Paper 2676.

- (2012). 'Negative and positive assimilation, skill transferability, and linguistic distance'. Journal of Human Capital 6.1, pp. 35-55.

Clark, K. and S. Drinkwater (1998). 'Ethnicity and self-employment in Britain'. Oxford Bulletin of Economics and Statistics 60.3, pp. 383-407.

Duleep, H. O. and M. C. Regets (1999). 'Immigrants and human-capital investment'. The American Economic Review 89.2, pp. 186-191.

Dustmann, C. and F. Fabbri (2003). 'Language proficiency and labour market performance of immigrants in the UK'. Economic Journal 113.489, pp. 695-717.

Dustmann, C. and A. Van Soest (2001). 'Language fluency and earnings: estimations with misspecified indicators'. The Review of Economics and Statistics 83.4, pp. 663-674.

Evans, M. (1987). 'Language skill, language usage and opportunity: immigrants in the Australian labour market'. Sociology 21.2, pp. 253-274.

Ganzeboom, H. B. G., P. M. D. E. Graaf, and D. J. Treiman (1992). 'A standard international socio-economic occupational status index of occupational status'. Social Science Research 21, pp. 1-56. 
Granovetter, M. (1974). Getting a job: a study of contacts and careers. first edit. Harvard University Press, Cambridge, MA.

Ioannides, Y. M. and L. D. Loury (2004). 'Job information networks, neighborhood effects , and inequality'. Journal of Economic Literature XLII.December, pp. 1056-1093.

Iosifides, T., M. Lavrentiadou, E. Petracou, and A. Kontis (2007). 'Forms of social capital and the incorporation of Albanian Immigrants in Greece'. Journal of Ethnic and Migration Studies 33.8, pp. 1343-1361.

Kanas, A. and F. Van Tubergen (2006). 'The impact of human and social capital on immigrants' employment and occupational status'. Working paper.

Kanas, A., B. R. Chiswick, T. Van der Lippe, and F. Van Tubergen (2012). 'Social contacts and the economic performance of immigrants: a panel study of immigrants in Germany'. International Migration Review 46.3, pp. 680-709.

Kazemipur, A. (2006). 'The market value of friendship: social networks of immigrants'. Canadian Ethnic Studies Journal 38.2, pp. 47-71.

Lancee, B. (2010). 'The economic returns of immigrants' bonding and bridging social capital: the case of the Netherlands'. International Migration Review 44.1, pp. 202226 .

- (2012). 'Immigrant performance in the labour market'. PhD thesis. Univeristy of Amsterdam.

Lin, N. (1999). 'Social networks and status attainment'. Annual Review of Sociology 25, pp. $467-487$.

Lin, N., J. C. Vaughn, and W. M. Ensel (1981). 'Social resources and occupational status attainment'. Social Forces 59.4, pp. 1163-1181.

Martinovic, B., F. Van Tubergen, and I. Maas (2009). 'Dynamics of interethnic contact: a panel study of immigrants in the Netherlands'. European Sociological Review 25.3, pp. 303-318.

McManus, W., W. Gould, and F. Welch (1983). 'Earnings of Hispanic men: the role of English language proficiency'. Journal of Labor Economics 1.2, p. 101.

Mincer, J. (1974). Schooling, experience and earnings. New York, NY: National Bureau of Economic Research.

Montgomery, J. D. (1991). 'Social networks and labor-market: toward an economic analysis'. American Economic Review 81.5, pp. 1408-1418.

Mouw, T. (2003). 'Social capital and finding a job: do contacts matter?' American Sociological Review 68.6, p. 868.

Mullan, B. P. (1989). 'The impact of social networks on the occupational status of migrants'. International Migration 27.1, pp. 69-86. 
Nickell, S. (1982). 'The determinants of occupational success in Britain'. The Review of Economic Studies 49.1, pp. 43-53.

Oosterbeek, H. (1992). 'Essays on human capital theory'. PhD thesis. University of Amsterdam.

Piracha, M., M. Tani, and M. Vaira-Lucero (2014). 'Social capital and immigrants' labour market performance'. Papers in Regional Science.

Putnam, R. D. (2000). Bowling Alone: the Collapse and Revival of American Community. Simon and Schuster.

Van Ours, J. C. and J. Veenman (1999). 'The Netherlands : old emigrants-young immigrant country'. IZA Discussion Paper 80.

Wang, Z. (2016). 'A paradox of economic prosperity and social integration?' Available at SSRN: http://ssrn.com/abstract=2737601.

Woolcock, M. and D. Narayan (2000). 'Social capital: implications for development theory, research, and policy'. The World Bank Research Observer 15.2, pp. 225-249.

Xue, L. (2008). 'Social capital and employment entry of recent immigrants to Canada'. Working paper March.

Yao, Y. and J. C. Van Ours (2015). 'Language skills and labor market performance of immigrants in the Netherlands'. Labour Economics 34, pp. 76-85.

Zorlu, A. (2013). 'Occupational adjustment of immigrants in the Netherlands'. Journal of International Migration and Integration 14.4, pp. 711-731.

Zorlu, A. and J. Hartog (2001). 'Migration and immigrants: the case of the Netherlands'. Tinbergen Institute Discussion Paper 042/3.

- (2008). 'Employment assimilation of immigrants in the Netherlands: catching up and the irrelevance of education'. IZA Discussion Paper 3534. 


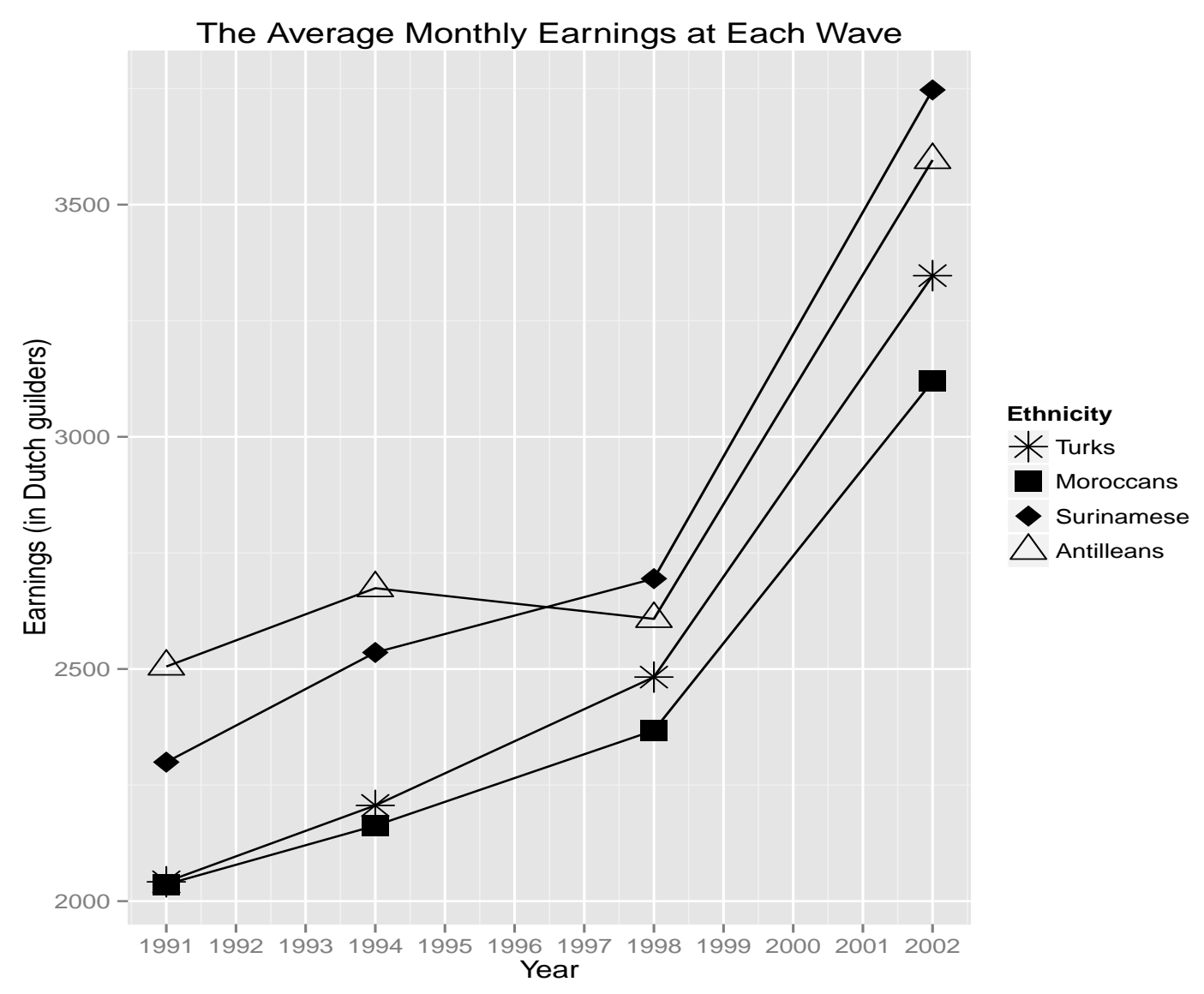

Figure 1: The Average Monthly Earnings of Adult Foreign-Born Men at Each Wave Source: SPVA 1991, 1994, 1998, 2002.

Note: In 2002, the currency changed from Dutch guilders to Euros. The exchange ratio 2.2:1 is used to unify the monetary unit across four waves. Earnings shown in this figure is not adjusted for inflation. 
Table 1: Descriptive Statistics for Cross-Sectional Data, Adult Foreign-Born Men

\begin{tabular}{|c|c|c|c|c|c|}
\hline Statistic & $\mathrm{N}$ & Mean & St. Dev. & Min & Max \\
\hline Earnings (in Dutch guilders) & 4,618 & $2,627.09$ & $1,137.78$ & 9.00 & $21,989.00$ \\
\hline Employed now & 8,913 & 0.58 & 0.49 & 0 & 1 \\
\hline Occupational status & 3,323 & 40.51 & 17.77 & 16 & 88 \\
\hline Age & 8,920 & 41.04 & 10.51 & 25 & 64 \\
\hline Turks & 8,920 & 0.35 & 0.48 & 0 & 1 \\
\hline Moroccans & 8,920 & 0.34 & 0.47 & 0 & 1 \\
\hline Surinamese & 8,920 & 0.19 & 0.39 & 0 & 1 \\
\hline Antilleans & 8,920 & 0.12 & 0.32 & 0 & 1 \\
\hline Dutch nationality & 8,920 & 0.53 & 0.50 & 0 & 1 \\
\hline YSM (in years) & 8,792 & 18.04 & 8.94 & 0.00 & 52.50 \\
\hline Married & 8,920 & 0.82 & 0.38 & 0 & 1 \\
\hline Number of children & 8,920 & 2.63 & 2.34 & 0 & 17 \\
\hline Motive: study & 8,920 & 0.11 & 0.31 & 0 & 1 \\
\hline Motive: family & 8,920 & 0.31 & 0.46 & 0 & 1 \\
\hline Motive: work & 8,920 & 0.43 & 0.50 & 0 & 1 \\
\hline Motive: others & 8,920 & 0.15 & 0.36 & 0 & 1 \\
\hline No edu. in OC & 8,698 & 0.33 & 0.47 & 0 & 1 \\
\hline Primary edu. in OC & 8,698 & 0.35 & 0.48 & 0 & 1 \\
\hline Lower edu. in OC & 8,698 & 0.16 & 0.37 & 0 & 1 \\
\hline Intermed. edu. in $\mathrm{OC}$ & 8,698 & 0.13 & 0.33 & 0 & 1 \\
\hline Higher edu. in OC & 8,698 & 0.03 & 0.17 & 0 & 1 \\
\hline No edu. in NL & 8,581 & 0.69 & 0.46 & 0 & 1 \\
\hline Primary edu. in NL & 8,581 & 0.10 & 0.29 & 0 & 1 \\
\hline Lower edu. in NL & 8,581 & 0.08 & 0.28 & 0 & 1 \\
\hline Intermed. edu. in NL & 8,581 & 0.07 & 0.26 & 0 & 1 \\
\hline Higher edu. in NL & 8,581 & 0.06 & 0.23 & 0 & 1 \\
\hline Exp. in OC (in years) & 8,531 & 4.85 & 3.29 & 0.00 & 21.36 \\
\hline Exp. in NL (in years) & 8,833 & 12.17 & 8.56 & 0.00 & 48.00 \\
\hline Work in primary sector & 8,920 & 0.05 & 0.22 & 0 & 1 \\
\hline Work in secondary sector & 8,920 & 0.28 & 0.45 & 0 & 1 \\
\hline Work in tertiary sector & 8,920 & 0.29 & 0.45 & 0 & 1 \\
\hline Contract working hours & 5,025 & 37.92 & 7.25 & 0 & 96 \\
\hline Ethnic concentration & 6,938 & 4.78 & 2.52 & 0.26 & 9.73 \\
\hline
\end{tabular}

Respondents are those reported as the household head by the household members.

Earnings are measured as monthly labour market income.

Earnings are not adjusted for inflation.

Occupational status is measured in terms of the International Socio-Economic Index (ISEI).

The means of working sector variables do not sum up to 1 because of 'N.A.' option.

Contract working hours are measured per week.

Ethnic concentration is measured in percentages.

Source: SPVA 1991, 1994, 1998, 2002. 
Table 2: Descriptive Statistics of Social Contacts and Dutch Language Proficiency across Ethnicity for Cross-Sectional Data, Adult Foreign-Born Men

\begin{tabular}{lcccc}
\hline & Turks & Moroccans & Surinamese & Antilleans \\
\hline During free time: more contact with co-ethnics & 0.48 & 0.29 & 0.29 & 0.19 \\
During free time: equal contacts & 0.19 & 0.28 & 0.40 & 0.33 \\
During free time: more contact with Dutch & 0.07 & 0.07 & 0.18 & 0.38 \\
At work: more contact with co-ethnics & 0.08 & 0.06 & 0.03 & 0.03 \\
At work: equal contacts & 0.23 & 0.22 & 0.19 & 0.09 \\
At work: more contact with Dutch & 0.22 & 0.19 & 0.48 & 0.56 \\
No membership & 0.77 & 0.83 & 0.65 & 0.64 \\
Ethnic org. membership & 0.16 & 0.10 & 0.17 & 0.08 \\
Dutch org. membership & 0.08 & 0.06 & 0.18 & 0.29 \\
Do not speak Dutch & 0.38 & 0.29 & 0.03 & 0.04 \\
Dutch: not very well & 0.42 & 0.43 & 0.12 & 0.23 \\
Dutch: very well & 0.20 & 0.28 & 0.85 & 0.72 \\
\hline
\end{tabular}

The social contacts and language variables are dichotomous with a value of either 0 or 1 . The figures in the table are the percentage of respondents in the total sample that fit the description of the first column within each ethnic group.

Sample size: 13023.

Source: SPVA 1991, 1994, 1998, 2002. 
Table 3: Cross-Section Regression Analysis of Earnings, Employment and Occupational Status, Adult Foreign-Born Men

\begin{tabular}{|c|c|c|c|}
\hline & Earnings & Employment & ISEI \\
\hline Constant & $5.178(0.182)^{* * *}$ & $-0.068(0.348)$ & $57.151(2.373)^{* * *}$ \\
\hline \multicolumn{4}{|l|}{ Social Contacts } \\
\hline Free time: equal contact & $-0.020(0.025)$ & $0.273(0.123)^{* *}$ & $0.631(0.680)$ \\
\hline Free time: more with Dutch & $-0.045(0.036)$ & $0.187(0.180)$ & $-1.423(0.952)$ \\
\hline At work: equal contact & $0.008(0.023)$ & & $-1.082(1.055)$ \\
\hline At work: more with Dutch & $0.015(0.023)$ & & $1.072(1.071)$ \\
\hline Ethnic org. membership & $0.019(0.023)$ & $0.107(0.122)$ & $1.653(0.685)^{* *}$ \\
\hline Dutch org. membership & $0.039(0.036)$ & $0.263(0.172)$ & $2.505(0.804)^{* * *}$ \\
\hline \multicolumn{4}{|l|}{ Human Capital } \\
\hline Dutch: not very well & $-0.015(0.020)$ & $0.277(0.112)^{* *}$ & $-0.171(0.678)$ \\
\hline Dutch: very well & $0.060(0.019)^{*}$ & $0.815(0.139)^{* * *}$ & $1.044(0.792)$ \\
\hline Primary edu. in OC & $-0.007(0.023)$ & $-0.048(0.106)$ & $-1.270(0.588)^{*}$ \\
\hline Lower edu. in OC & $-0.010(0.034)$ & $-0.039(0.154)$ & $0.097(0.757)$ \\
\hline Intermed. edu. in OC & $0.055(0.039)$ & $-0.003(0.155)$ & $1.933(0.867)^{* *}$ \\
\hline Higher edu. in OC & $0.099(0.085)^{*}$ & $0.139(0.270)$ & $9.547(2.025)^{* * *}$ \\
\hline Primary edu. in NL & $-0.002(0.030)$ & $0.053(0.138)$ & $2.395(0.862)^{* * *}$ \\
\hline Lower edu. in NL & $0.065(0.026)^{*}$ & $0.477(0.193)^{* * *}$ & $0.177(0.826)$ \\
\hline Intermed. edu. in NL & $0.088(0.037)^{* *}$ & $0.979(0.245)^{* * *}$ & $4.890(1.059)^{* * *}$ \\
\hline Higher edu. in NL & $0.168(0.062)^{* * *}$ & $2.145(0.370)^{* * *}$ & $18.946(1.335)^{* * *}$ \\
\hline Exp. in NL & $0.007(0.005)$ & $0.282(0.023)^{* * *}$ & $0.224(0.136)^{*}$ \\
\hline Exp. in $\mathrm{OC}$ & $-0.002(0.008)$ & $-0.229(0.042)^{* * *}$ & $-0.452(0.265)^{*}$ \\
\hline Exp. in NL squared/100 & $-0.006(0.018)$ & $-0.283(0.069)^{* * *}$ & $-0.889(0.398)^{* *}$ \\
\hline Exp. in OC squared/100 & $0.021(0.051)$ & $0.599(0.291)^{* *}$ & $3.100(2.166)^{*}$ \\
\hline \multicolumn{4}{|l|}{ Control Variables } \\
\hline Moroccans & $-0.026(0.019)$ & $-0.218(0.108)^{* *}$ & $-1.719(0.617)^{* *}$ \\
\hline Surinamese & $-0.023(0.038)$ & $1.007(0.181)^{* * *}$ & $0.603(0.898)$ \\
\hline Antilleans & $0.048(0.045)$ & $0.984(0.230)^{* * *}$ & $0.527(1.120)$ \\
\hline Dutch nationality & $-0.004(0.018)$ & $0.101(0.107)$ & $0.275(0.560)$ \\
\hline YSM & $0.006(0.010)$ & $-0.158(0.024)^{* * *}$ & $-0.236(0.144)$ \\
\hline YSM squared/100 & $-0.012(0.030)$ & $-0.048(0.061)$ & $0.979(0.367)^{* * *}$ \\
\hline Married & $0.060(0.030)^{* *}$ & $0.786(0.128)^{* * *}$ & $-0.499(0.743)$ \\
\hline Number of children & $0.007(0.008)$ & $-0.062(0.026)^{* *}$ & $0.202(0.170)$ \\
\hline Inflation factor & $1.495(0.093)^{* * *}$ & & \\
\hline Contract working hours & $0.014(0.002)^{* * *}$ & & \\
\hline Ethnic concentration & $0.010(0.006)^{*}$ & $0.035(0.030)$ & $0.184(0.151)$ \\
\hline $\mathrm{R}^{2}$ & 0.144 & & 0.480 \\
\hline Adj. $R^{2}$ & 0.131 & & 0.471 \\
\hline Num. obs. & 3160 & 4715 & 2990 \\
\hline Log Likelihood & & -1773.689 & \\
\hline
\end{tabular}

${ }^{* * *} p<0.01,{ }^{* *} p<0.05,{ }^{*} p<0.1$

Standard errors in the parentheses are clustered on respondent ID.

The dependent variable of column (1) is the natural logarithm of earnings. Column (2) is estimated using a logistic regression model. The dependent variable of column (3) is the International Socio-Economic Index.

The reference for each categorical variable is as follows. Contact composition during free time: more contact with co-ethnics. Contact composition at work: more contact with co-ethnics. Organisation membership: no membership. Dutch proficiency: do not speak Dutch $\mathcal{Q}^{\mathrm{r}}$ find it very difficult. Education in OC: no education. Education in NL: no education. Ethnicity: Turks.

The inflation factor is the Consumer Price Index (CPI) in year 1991, 1994, 1998 and 2002.

Year effect, city effect and sector effect are controlled in the regressions.

The variance inflation factors for social contact variables and language proficiency variable are all smaller than 4 , implying no multicollinearity problem. 


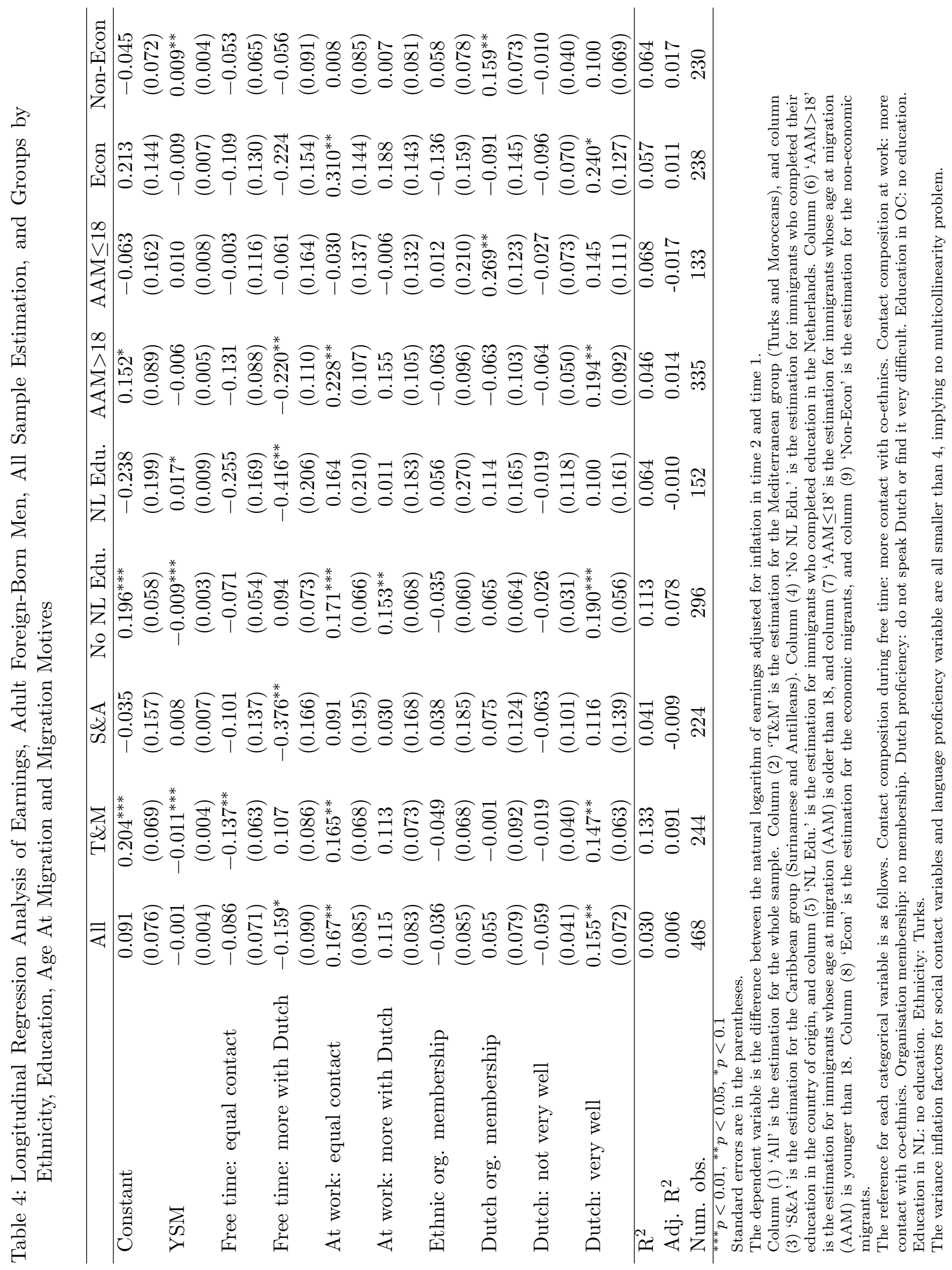




\section{Appendix}

Table A1: The Definitions and Coding of the Variables in 'Social Position and Use of Public Facilities by Immigrants' (SPVA)

\begin{tabular}{|c|c|}
\hline Variables & Questions asked in the survey and coding \\
\hline Earnings & $\begin{array}{l}\text { 'What is your net monthly income from employment?' } \\
\text { In year } 2002 \text {, the currency changed from Dutch guilders } \\
\text { to Euros. The exchange ratio } 2.2: 1 \text { is used to unify } \\
\text { the monetary unit across four waves. }\end{array}$ \\
\hline Employed now & $\begin{array}{l}\text { 'Do you have a paid job at the moment?' } \\
0-\text { No; } \\
\text { 1-Yes. }\end{array}$ \\
\hline Occupations & $\begin{array}{l}\text { 'What kind of work are you doing at the moment?' } \\
\text { The answers are coded either as International Standard } \\
\text { Classification of Occupations (ISCO-88) or Standaard } \\
\text { Beroepenclassificatie } 1992 \text { (SBC 1992) in Dutch code. }\end{array}$ \\
\hline Contract working hours & $\begin{array}{l}\text { 'How many hours do you work according to your employment } \\
\text { contract?' }\end{array}$ \\
\hline Education in $\mathrm{OC}$ & $\begin{array}{l}\text { 'What is the highest degree you have completed in your } \\
\text { country of origin?' } \\
\text { 0-No degree; } \\
\text { 1-Degree in primary education (LO); } \\
\text { 2-Degree in secondary education (LBO/MAVO); } \\
\text { 3-Degree in intermediate education (MBO/HAVO/VWO); } \\
\text { 4-Degree in higher education (HBO/WO). } \\
\text { This question was originally asked in the survey as the } \\
\text { degree completed outside Netherlands. Since pre-migration } \\
\text { human capital is not the main focus of this paper, we } \\
\text { assume most of the schooling is completed in the country } \\
\text { of origin. }\end{array}$ \\
\hline Education in NL & $\begin{array}{l}\text { 'What is the highest degree you have completed in } \\
\text { the Netherlands?' } \\
\text { 0-No degree; } \\
\text { 1-Degree in primary education (LO); } \\
\text { 2-Degree in secondary education (LBO/MAVO); }\end{array}$ \\
\hline & Continued on next page \\
\hline
\end{tabular}


Table A1 - continued from previous page

\begin{tabular}{|c|c|}
\hline Variables & Questions asked in the survey and coding \\
\hline & $\begin{array}{l}\text { 3-Degree in intermediate education }(\mathrm{MBO} / \mathrm{HAVO} / \mathrm{VWO}) \text {; } \\
\text { 4-Degree in higher education }(\mathrm{HBO} / \mathrm{WO}) \text {. }\end{array}$ \\
\hline Work experience in $\mathrm{OC}$ & $\begin{array}{l}\text { 'How long have you been in paid work in total in } \\
\text { country of origin?' } \\
\text { This question was asked only in the } 1991 \\
\text { questionnaires. To supplement this variable in } \\
\text { the other three waves, we regress reported } 1991 \\
\text { work experience in OC on individual background } \\
\text { characteristics (gender, age, years since migration, } \\
\text { total education, etc) and predict values for the other } \\
\text { three waves. }\end{array}$ \\
\hline Work experience in NL & 'How long have you worked in total in the Netherlands?' \\
\hline $\begin{array}{l}\text { Dutch language } \\
\text { proficiency }\end{array}$ & $\begin{array}{l}\text { 'When you are in a conversation, do you have any } \\
\text { difficulty in using Dutch language?' } \\
\text { 0-Yes, very difficult/ do not speak Dutch at all; } \\
\text { 1-Yes, sometimes; } \\
\text { 2-No, never. }\end{array}$ \\
\hline $\begin{array}{l}\text { Contact composition } \\
\text { during free time }\end{array}$ & $\begin{array}{l}\text { 'In your spare time, do you have more contact with } \\
\text { Dutch people or do you have more contact with people } \\
\text { from your own ethnic group?' } \\
\text { 1-More co-ethnic contact; } \\
\text { 2-Both equally; } \\
\text { 3-More contact with Dutch people. }\end{array}$ \\
\hline $\begin{array}{l}\text { Contact composition } \\
\text { at work }\end{array}$ & $\begin{array}{l}\text { 'At work, do you have more contact with } \\
\text { Dutch people or do you have more contact with people } \\
\text { from your own ethnic group?' } \\
\text { 1-More co-ethnic contact; } \\
\text { 2-Both equally; } \\
\text { 3-More contact with Dutch people. } \\
\text { This variable is not recorded in 2002. Similar with } \\
\text { what has been done for work experience in OC, we use } \\
\text { the regression technique to predict this variable in } 2002 .\end{array}$ \\
\hline Organisation membership & Q1: 'Are you a member of an association or club?' \\
\hline & Continued on next page \\
\hline
\end{tabular}


Table A1 - continued from previous page

\begin{tabular}{|c|c|}
\hline Variables & Questions asked in the survey and coding \\
\hline & $\begin{array}{l}0 \text {-No; } \\
\text { 1-Yes. } \\
\text { Q2: 'Are there many, few or almost no co-ethnic } \\
\text { members of these associations?' } \\
\text { 0-Almost no; } \\
\text { 1-Few; } \\
\text { 2-Many. }\end{array}$ \\
\hline Ethnicity & $\begin{array}{l}\text { 'What is your ethnic group?' } \\
\text { 1-Turks; } \\
\text { 2-Moroccans; } \\
\text { 3-Surinamese; } \\
\text { 4-Antilleans. }\end{array}$ \\
\hline Municipality & $\begin{array}{l}\text { Registered residence municipality } \\
\text { 1-Amsterdam; 2-Rotterdam; 3-Den Haag; 4-Utrecht; } \\
\text { 5-Eindhoven; 6-Enschede; 7-Almere; 8-Alphen aan den Rijn; } \\
\text { 9-Bergen op Zoom; 10-Hoogezand-Sappemeer; 11-Delft; } \\
\text { 12-Dordrecht; 13-Tiel. } \\
\text { Leeuwarden, Spijkenisse, Zwijndrecht and Gornichem are } \\
\text { recoded in SPVA 1991, but not in other waves. And hence } \\
\text { we drop the observations in these municipalities. }\end{array}$ \\
\hline Nationality & $\begin{array}{l}\text { 'What is your nationality?' } \\
\text { 1-Origin country's nationality; } \\
\text { 2-Dutch nationality; } \\
\text { 3-Both the origin country's and Dutch nationalities; } \\
\text { 4-Others. } \\
\text { The answers are recoded to a dichotomous variable } \\
\text { which equals } 1 \text { if the respondent reported having } \\
\text { Dutch nationality, and } 0 \text { otherwise. }\end{array}$ \\
\hline Married & $\begin{array}{l}\text { 'What is your marital status?' } \\
\text { 1-Married; 2-Divorced; 3-Widow/widower; } \\
\text { 4-Never been married. }\end{array}$ \\
\hline Number of children & $\begin{array}{l}\text { 'How many children are there living at home?' } \\
\text { 'How many children are not living at home?' }\end{array}$ \\
\hline
\end{tabular}


Table A1 - continued from previous page

\begin{tabular}{|l|l|}
\hline Variables & Questions asked in the survey and coding \\
\hline & These two answers are summed up. \\
\hline Years since migration & 'What is your length of stay in the Netherlands?' \\
\hline Migration motives & 'You are not born in the Netherlands. What was the main \\
& reason for coming to the Netherlands?' \\
& 1-Work; 2-Study; 3-Social safety; \\
& 4-Political situation in origin country; 5-Family reunion; \\
& 6-Marriage, family formation; 7-Come along with parents; \\
& 8-Others. \\
& The answers are recoded to four main categories: work, \\
& study, family and other reasons. \\
\hline
\end{tabular}




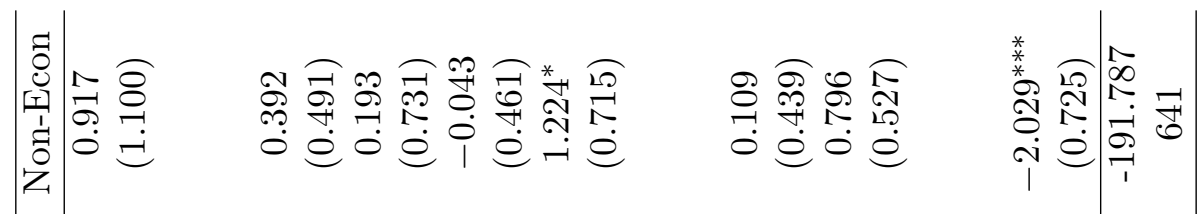

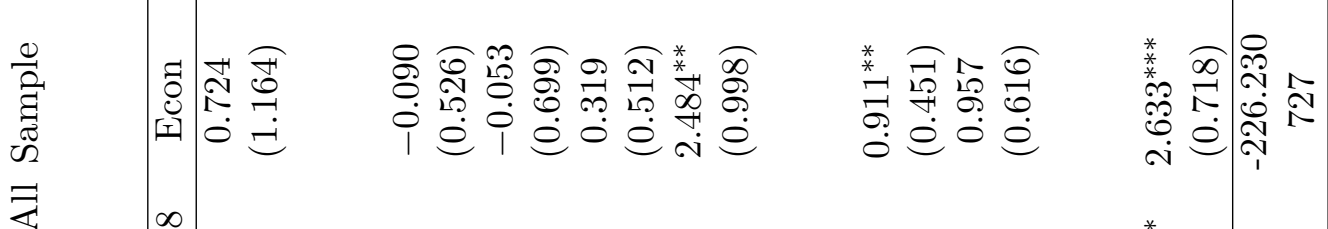

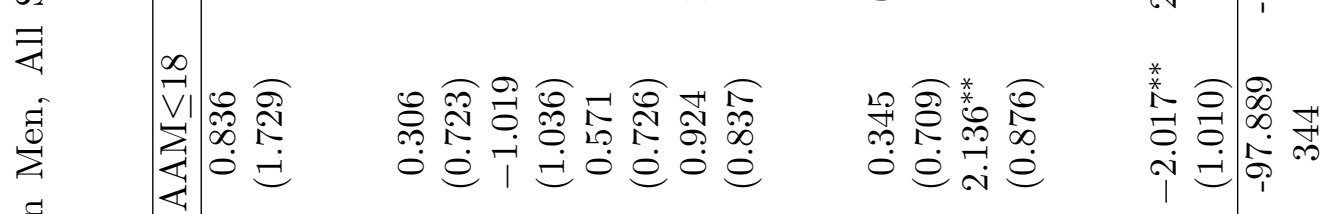

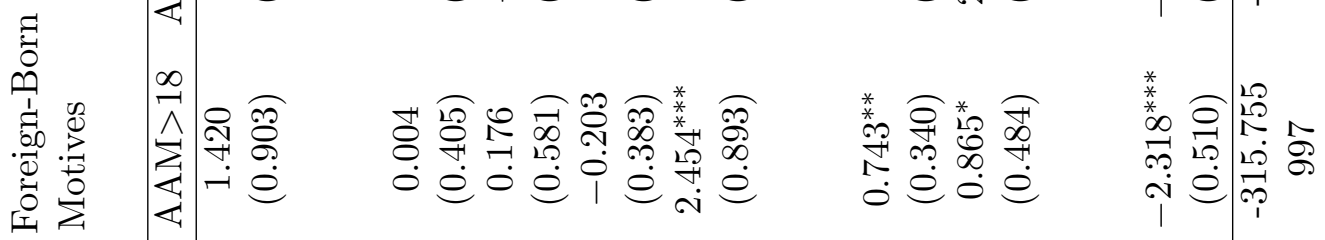

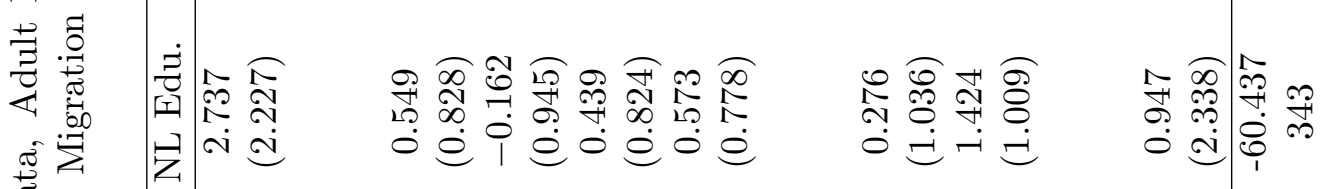

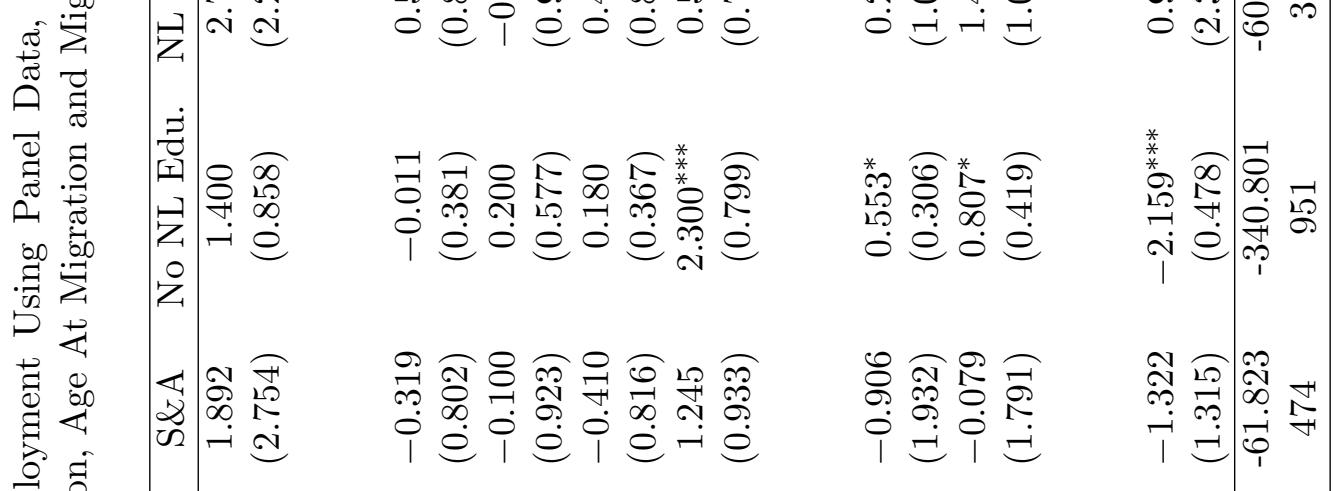

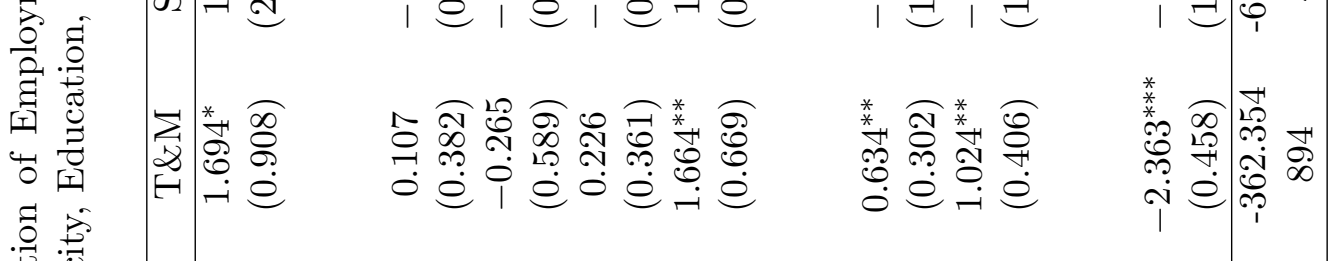

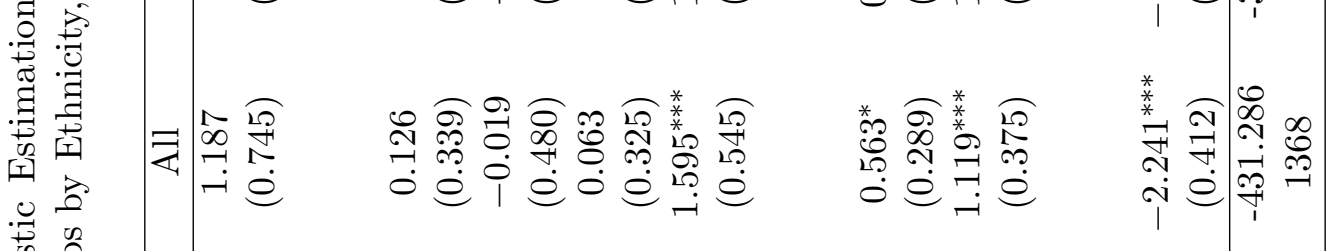

善高

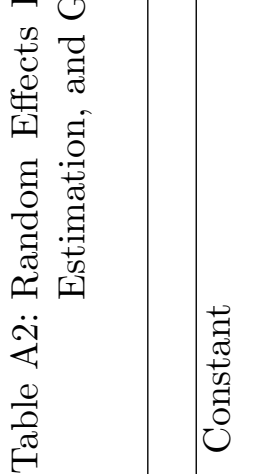

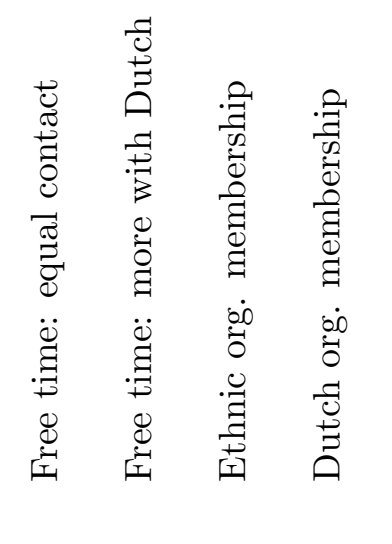

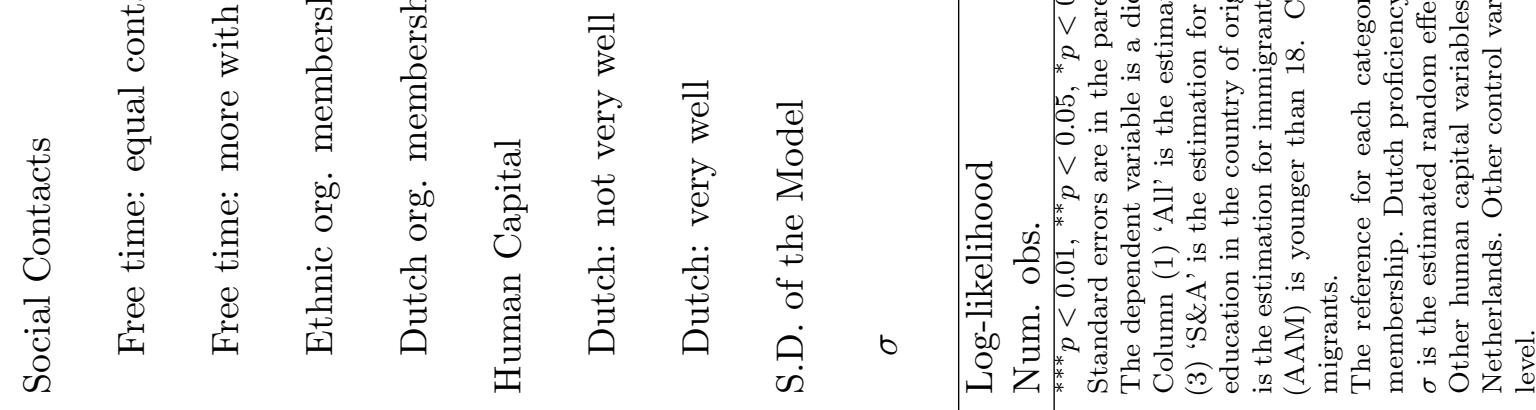

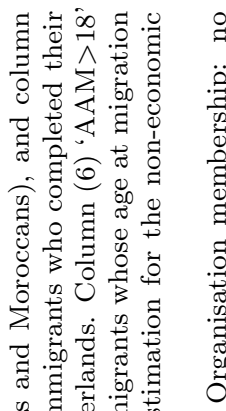

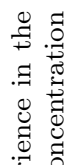

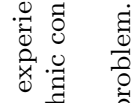

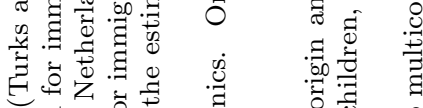

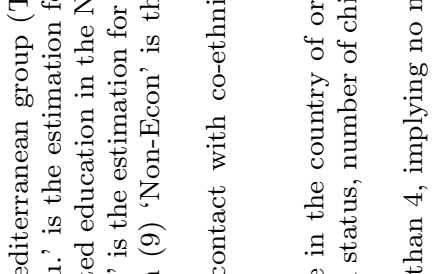

贾

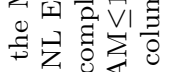

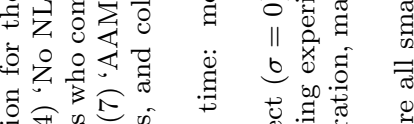

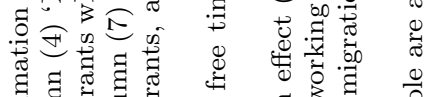

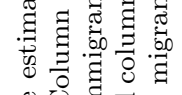

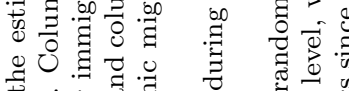

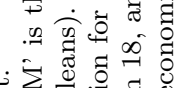

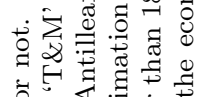

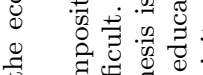

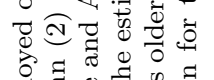

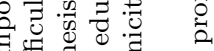

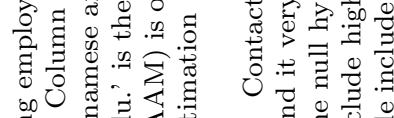

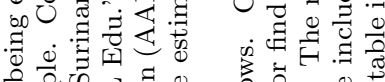

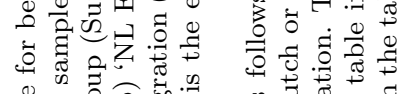

in 0

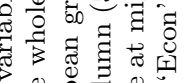

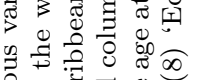

I :

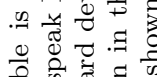

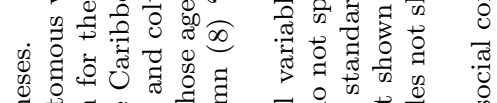

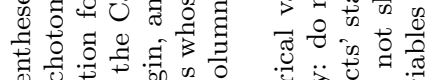

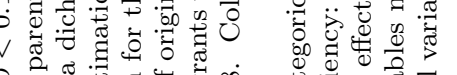

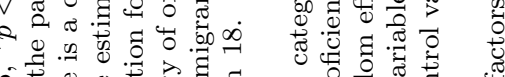

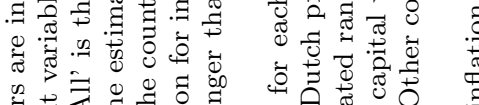

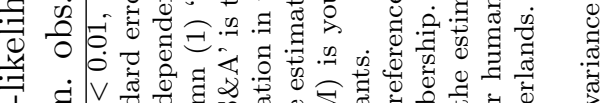

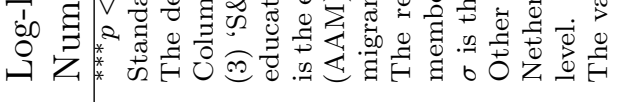


Table A3: Fixed Effects Estimation of Panel Data on Occupational Status, Adult ForeignBorn Men: All Sample and Groups by Occupation

\begin{tabular}{lccc}
\hline & All & Blue-Collar & White-Collar \\
\hline Constant & 0.000 & $3.942^{* * *}$ & $-3.499^{* * *}$ \\
YSM & $(0.397)$ & $(0.625)$ & $(0.443)$ \\
& $-1.179^{* * *}$ & $-1.384^{* * *}$ & $-0.695^{* * *}$ \\
Free time: equal contact & $(0.176)$ & $(0.289)$ & $(0.194)$ \\
& 1.200 & -3.379 & $4.280^{*}$ \\
Free time: more with Dutch & $(2.051)$ & $(3.103)$ & $(2.373)$ \\
& 1.861 & -1.399 & 3.481 \\
At work: equal contact & $(2.692)$ & $(3.962)$ & $(3.228)$ \\
& $6.501^{* *}$ & 6.380 & 5.403 \\
At work: more with Dutch & $(3.220)$ & $(5.865)$ & $(3.284)$ \\
& $6.580^{* *}$ & 6.057 & 5.551 \\
Dutch visits sometimes & $(3.345)$ & $(5.782)$ & $(3.499)$ \\
& -3.111 & -4.873 & -2.217 \\
Dutch visits frequently & $(2.107)$ & $(3.488)$ & $(2.300)$ \\
& 3.185 & 2.295 & 1.576 \\
Ethnic org. membership & $(2.500)$ & $(3.935)$ & $(2.849)$ \\
& $5.490^{* *}$ & 4.573 & $5.217^{*}$ \\
Dutch org. membership & $(2.509)$ & $(4.137)$ & $(2.709)$ \\
& 1.668 & 2.283 & -0.015 \\
Dutch: not very well & $(2.294)$ & $(3.254)$ & $(2.838)$ \\
& 2.187 & 4.280 & 1.154 \\
Dutch: very well & $(2.487)$ & $(4.416)$ & $(2.577)$ \\
& 2.962 & 3.371 & 2.270 \\
& $(2.841)$ & $(4.805)$ & $(3.019)$ \\
$\mathrm{R}^{2}$ & 0.089 & 0.102 & 0.069 \\
Adj. $\mathrm{R}^{2}$ & 0.070 & 0.062 & 352 \\
Num. obs. & 655 & 303 &
\end{tabular}

${ }^{* * *} p<0.01,{ }^{* *} p<0.05,{ }^{*} p<0.1$
Standard errors are in the parentheses.

The dependent variable is ISEI. The fixed effects estimator is obtained by within transformation. Column (1) is the estimation for the whole panel data sample. Column (2) is the estimation for immigrants who are blue-collar workers. Column (3) is the estimation for immigrants who are white-collar workers.

The reference for each categorical variable is as follows. Contact composition during free time: more contact with co-ethnics. Contact composition at work: more contact with co-ethnics. Organisation membership: no membership. Dutch proficiency: do not speak Dutch or find it very difficult.

The variance inflation factors for social contact variables and language proficiency variable are all smaller than 4 , implying no multicollinearity problem. 
Table A4: Heckman Selection Model for Earnings, Employment, and Occupational Status, Adult Foreign-Born Men

\begin{tabular}{|c|c|c|c|}
\hline & Earnings & Employment & ISEI \\
\hline Constant & $4.884(0.839)^{* * *}$ & $0.938(0.152)^{* * *}$ & $24.227(5.853)^{* * *}$ \\
\hline \multicolumn{4}{|l|}{ Social Contacts } \\
\hline Free time: equal contact & $-0.018(0.066)$ & $0.030(0.031)$ & $1.722(1.606)$ \\
\hline Free time: more with Dutch & $-0.061(0.078)$ & $-0.024(0.041)$ & $0.595(2.091)$ \\
\hline At work: equal contact & $0.030(0.077)$ & & $-0.768(2.754)$ \\
\hline At work: more with Dutch & $0.016(0.074)$ & & $0.427(2.162)$ \\
\hline Ethnic org. membership & $0.074(0.063)$ & $0.036(0.031)$ & $3.613(1.684)^{* *}$ \\
\hline Dutch org. membership & $0.143(0.062)^{* *}$ & $0.010(0.034)$ & $2.561(1.652)$ \\
\hline \multicolumn{4}{|l|}{ Human Capital } \\
\hline Dutch: not very well & $0.037(0.062)$ & $0.079(0.029)^{* * *}$ & $-0.760(1.607)$ \\
\hline Dutch: very well & $0.115(0.076)$ & $0.162(0.037)^{* * *}$ & $2.393(1.952)$ \\
\hline Primary edu. in OC & $-0.024(0.054)$ & $-0.012(0.026)$ & $-2.822(1.339)^{* *}$ \\
\hline Lower edu. in OC & $0.033(0.067)$ & $0.033(0.036)$ & $-0.418(1.692)$ \\
\hline Intermed. edu. in $\mathrm{OC}$ & $0.072(0.075)$ & $-0.011(0.037)$ & $-0.512(1.847)$ \\
\hline Higher edu. in OC & $-0.142(0.120)$ & $-0.029(0.060)$ & $13.468(2.919)^{* * *}$ \\
\hline Primary edu. in NL & $-0.079(0.070)$ & $0.006(0.035)$ & $1.759(2.003)$ \\
\hline Lower edu. in NL & $0.018(0.089)$ & $0.080(0.045)^{*}$ & $-3.201(2.903)$ \\
\hline Intermed. edu. in NL & $0.160(0.113)$ & $0.097(0.055)^{*}$ & $4.164(3.169)$ \\
\hline Higher edu. in NL & $-0.139(0.097)$ & $0.191(0.052)^{* * *}$ & $16.141(2.962)^{* * *}$ \\
\hline Exp. in NL & $0.004(0.012)$ & $0.035(0.005)^{* * *}$ & $-0.133(0.288)$ \\
\hline Exp. in $\mathrm{OC}$ & $-0.014(0.019)$ & $-0.040(0.009)^{* * *}$ & $-0.737(0.493)$ \\
\hline Exp. in NL squared/100 & $-0.019(0.037)$ & $-0.024(0.016)$ & $-0.398(0.862)$ \\
\hline Exp. in OC squared/100 & $0.129(0.139)$ & $0.165(0.068)^{* *}$ & $5.378(3.592)$ \\
\hline \multicolumn{4}{|l|}{ Control Variables } \\
\hline Moroccans & $-0.005(0.071)$ & $-0.014(0.031)$ & $-2.837(1.639)^{*}$ \\
\hline Surinamese & $0.017(0.096)$ & $0.061(0.045)$ & $2.433(2.301)$ \\
\hline Antilleans & $-0.010(0.091)$ & $0.107(0.048)^{* *}$ & $4.388(2.346)^{*}$ \\
\hline Dutch nationality & $0.000(0.052)$ & $0.047(0.025)^{*}$ & $-1.492(1.298)$ \\
\hline YSM & $-0.005(0.019)$ & $-0.038(0.008)^{* * *}$ & $0.264(0.437)$ \\
\hline YSM squared/100 & $0.023(0.046)$ & $0.024(0.021)$ & $0.106(1.193)$ \\
\hline Married & $0.140(0.063)^{* *}$ & $0.056(0.033)^{*}$ & $0.589(1.536)$ \\
\hline Number of children & $0.014(0.014)$ & $0.001(0.007)$ & $0.481(0.368)$ \\
\hline Inflation factor & $1.764(0.825)^{* *}$ & & \\
\hline Contract working hours & $0.014(0.003)^{* * *}$ & & \\
\hline Ethnic concentration & $0.006(0.016)$ & $0.011(0.009)$ & $0.462(0.459)$ \\
\hline \multicolumn{4}{|l|}{ Selectivity Coefficient } \\
\hline Inverse Mill's ratio & $-0.094(0.361)$ & $-0.232(0.172)$ & $-1.212(9.379)$ \\
\hline $\mathrm{R}$ squared & 0.070 & 0.250 & 0.400 \\
\hline Adj. R squared & 0.050 & 0.240 & 0.380 \\
\hline Num. obs. & 3155 & 4708 & 3490 \\
\hline
\end{tabular}

${ }^{* * *} p<0.01,{ }^{* *} p<0.05,{ }^{*} p<0.1$

Standard errors are in the parentheses.

The dependent variable of column (1) is the natural logarithm of earnings. Column (2) is estimated using a linear probability model. The dependent variable of column (3) is ISEI.

The reference for each categorical variable is as follows. Contact composition during free time: more contact with co-ethnics. Contact composition at work: mok 4 contact with co-ethnics. Organisation membership: no membership. Dutch proficiency: do not speak Dutch or find it very difficult. Education in OC: no education. Education in NL: no education. Ethnicity: Turks.

The inflation factor is the Consumer Price Index (CPI) in year 1991, 1994, 1998 and 2002.

Year effect, city effect and sector effect are controlled in the regressions.

For inverse Mill's ratio, the null hypothesis is that there is no selection bias. 
Table A5: Longitudinal Regression Analysis of Earnings Using Lagged Social Contact Variables, Adult Foreign-Born Men

\begin{tabular}{|c|c|}
\hline & Earnings \\
\hline Constant & $5.280(0.335)^{* * *}$ \\
\hline \multicolumn{2}{|l|}{ Social Contacts } \\
\hline Free time: equal contact $(\mathrm{t}-1)$ & $0.045(0.056)$ \\
\hline Free time: more with Dutch $(\mathrm{t}-1)$ & $0.043(0.069)$ \\
\hline At work: equal contact (t-1) & $-0.055(0.088)$ \\
\hline At work: more with Dutch $(\mathrm{t}-1)$ & $0.042(0.082)$ \\
\hline Ethnic org. membership (t-1) & $0.148(0.063)^{* *}$ \\
\hline Dutch org. membership (t-1) & $0.106(0.058)^{*}$ \\
\hline \multicolumn{2}{|l|}{ Human Capital } \\
\hline Dutch: not very well (t-1) & $0.010(0.060)$ \\
\hline Dutch: very well $(\mathrm{t}-1)$ & $0.018(0.069)$ \\
\hline Primary edu. in OC & $-0.050(0.057)$ \\
\hline Lower edu. in OC & $0.051(0.067)$ \\
\hline Intermed. edu. in $\mathrm{OC}$ & $0.022(0.076)$ \\
\hline Higher edu. in OC & $0.104(0.160)$ \\
\hline Primary edu. in NL & $-0.153(0.071)^{* *}$ \\
\hline Lower edu. in NL & $-0.093(0.075)$ \\
\hline Intermed. edu. in NL & $0.055(0.075)$ \\
\hline Higher edu. in NL & $0.132(0.086)$ \\
\hline Exp. in NL & $0.007(0.011)$ \\
\hline Exp. in $\mathrm{OC}$ & $-0.015(0.021)$ \\
\hline Exp. in NL squared/100 & $-0.028(0.031)$ \\
\hline Exp. in OC squared/100 & $0.046(0.161)$ \\
\hline \multicolumn{2}{|l|}{ Control Variables } \\
\hline Moroccans & $-0.079(0.063)$ \\
\hline Surinamese & $-0.014(0.079)$ \\
\hline Antilleans & $0.074(0.094)$ \\
\hline Dutch nationality & $-0.035(0.058)$ \\
\hline YSM & $-0.015(0.013)$ \\
\hline YSM squared/100 & $0.049(0.030)$ \\
\hline Married & $0.089(0.061)$ \\
\hline Number of children & $0.029(0.014)^{* *}$ \\
\hline Inflation factor & $1.472(0.223)^{* * *}$ \\
\hline Contract working hours & $0.017(0.003)^{* * *}$ \\
\hline Ethnic concentration & $0.022(0.013)^{*}$ \\
\hline $\mathrm{R}^{2}$ & 0.306 \\
\hline Adj. $R^{2}$ & 0.239 \\
\hline Num. obs. & 568 \\
\hline
\end{tabular}

${ }^{* * *} p<0.01,{ }^{* *} p<0.05,{ }^{*} p<0.1$

Standard errors are in the parentheses.

The dependent variable of column (1) is the natural logarithm of earnings. Column (2) is estimated using a logistic regression model. Contact composition during free time: more contact with co-ethnics. Contact composition at work: more contact with co-ethnics. Organisation membership: no membership. Dutch proficiency: do not speak Dutch or find it very difficult. Education in OC: no education. Education in NL: no education. Ethnicity: Turks. The inflation factor is the Consumer Price Index (CPI) in year 1991, 1994, 1998 and 2002.

City effect and sector effect are controlled in the regressions.

The variance inflation factors for social contact variabłes and language proficiency variable are all smaller than 4 , implying no multicollinearity problem. 